\title{
THE RELATIONSHIP BETWEEN VOLCANIC ISLAND GENESIS AND THE INDO-AUSTRALIAN PACIFIC PLATE MARGINS IN THE EASTERN OUTER ISLANDS, SOLOMON ISLANDS, SOUTH-WEST PACIFIC
}

\author{
G. Wyn Hughes \\ Geological Division, Ministry of Natural Resources, \\ Honiara, Solomon Islands \\ (Received April 19, 1978; Revised October 6, 1978)
}

The Eastern Outer Islands form a group of small islands situated in the south-west Pacific Ocean, to the south-east of the main Solomon Islands chain, and to the north of the New Hebrides chain.

They are founded upon the northern part of the submarine Fiji Plateau and flanked by deep sea trenches on the western, northern and eastern sides, but by an east-west trending fracture zone on the southern side. Two south-easterly trending island chains can be recognized, the western chain includes the islands of Tinakula, Nendö, Vanikolo and Utupua, and the eastern chain includes the islands of the Duff Group, Anuta and Fatutaka. The island of Tikopia is situated midway between both chains. The Torres and Vitiaz Trenches form the western and eastern flanks respectively of the north Fiji Plateau, which is itself bordered to the west and east respectively by the Indo-Australian and Pacific lithospheric plates. A westerly extension of the Vitiaz Trench, known as the Cape Johnson Trough, forms the northern boundary. The south side of the region is delimited by the Hazel Holme Fracture Zone.

Volcanic rocks within the group range from picrite basalts, through basalts and andesites, to dacites. Mafic lavas predominate in the older islands of the western chain, two islands of the eastern chain and in samples dredged from the Vitiaz Trench. More sialic lavas are exposed in two islands of the eastern chain, the isolated island of Tikopia and also in the active volcanic island of Tinakula.

Petrologic, petrochemical, seismic and heat flow evidence suggests that the Eastern Outer Islands represent two, discrete south-easterly trending island arcs, each associated with the adjacent trench. The sequence of volcanic episodes can be best explained in terms of plate tectonics, in which the islands of the western chain were produced during two episodes of volcanic activity associated with an easterly inclined Torres subduction zone. Late Oligocene to early Miocene subduction produced the island of Nendö, but the islands of Utupua, Vanikolo and Tinakula were produced during the late Pliocene to Recent. The westerly-dipping Vitiaz subduction zone is postulated as a source from which the east facing Duffs-Anuta-Fatutaka island arc was produced during the Middle Miocene to late Pliocene.

\section{Introduction and Geological Setting}

The Solomon Islands form part of a discontinuous chain of islands which extend south-eastwards from New Guinea to Tonga, in the south-west Pacific Ocean.

The Eastern Outer Islands comprise a group of small, scattered islands which are situated approximately $450 \mathrm{~km}$ east of the main Solomon Islands chain, and approximately 


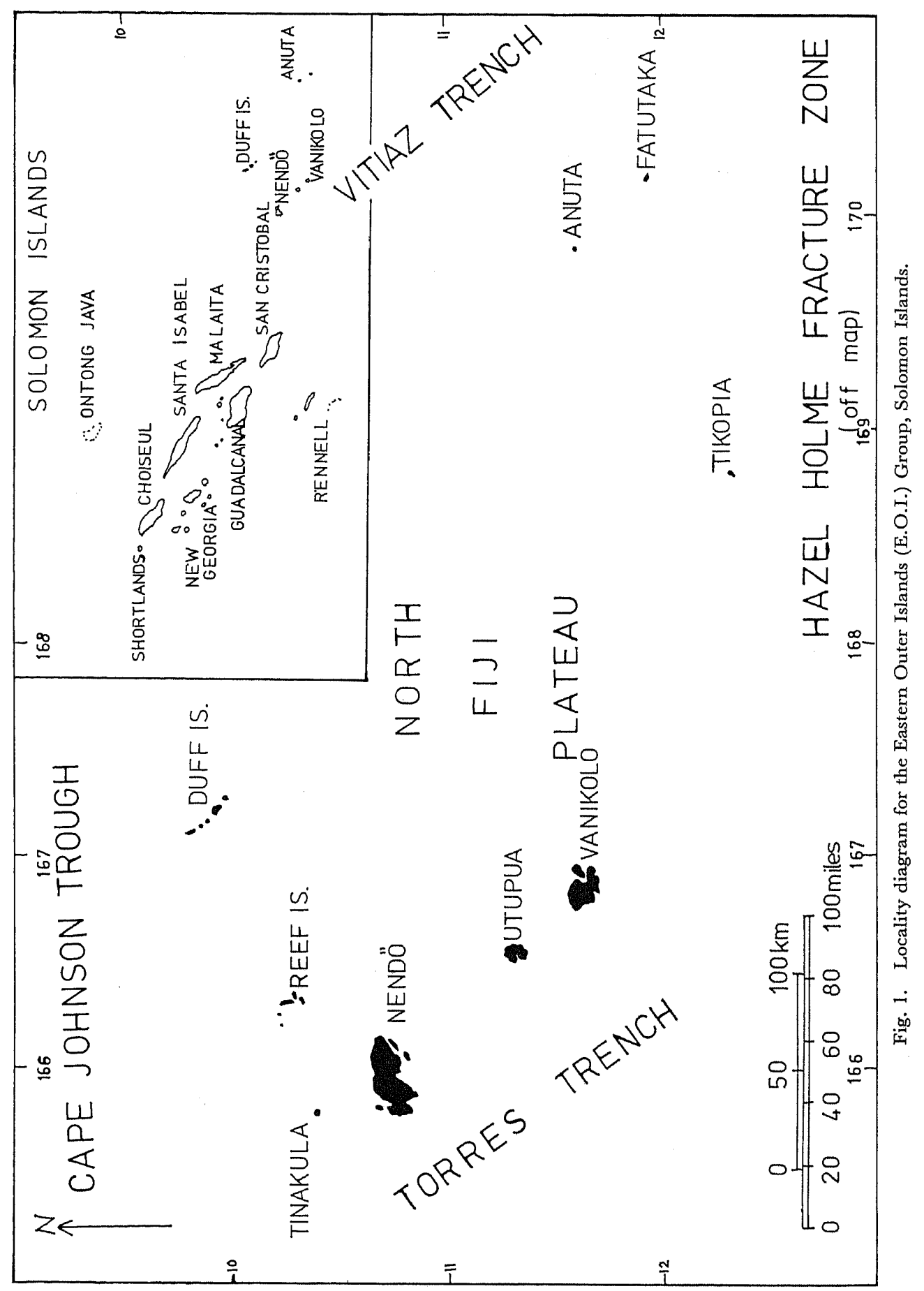


$130 \mathrm{~km}$ north of the New Hebrides. They were mapped geologically between 1968 and 1973 by the Geological Division of the Ministry of Natural Resources (then Geological Survey).

Tinakula, Nendö, Utupua and Vanikolo islands form a well-defined south-east trending chain in the west of the Group (Fig. 1). To the north-east of Nendö lie the Reef Islands. The Duff Islands, Anuta and Fatutaka form a poorly defined south-east trending chain in the east of the Group, and the isolated island of Tikopia is situated midway between both island chains. Volcanic cones are well preserved on the islands of Vanikolo, Utupua and Tikopia, as well as on the active volcano of Tinakula.

Eight of the nine islands and island groups are volcanogenic and range in age from late Oligocene to Recent; the Reef Islands have a biogenic origin, but are considered to have a volcanogenic base. Tinakula is the only active volcanic island in the Group while Nendö is the only island in the Group which is composed of both volcanic and sedimentary rocks.

\section{Summary of the Geology}

Nendö island contains a late Oligocene to early Miocene volcanic pile which was faulted and partly submerged during the Middle Miocene to late Pliocene. The lavas are commonly labradorite augite basalts with a variable porphyritic mode in which some horizons contain olivine phenocrysts and others, orthopyroxene. Radiometric dating on a sample from this basal lava succession gives an age of 26 my (Hughes $e t$ al., in press).

An episode of volcanism in the Middle Pliocene gave submarine lavas which lie upon a sequence of calcareous volcaniclastic sediments which contain planktonic foraminifera of Middle Pliocene age (Hughes, 1977). The lavas consist typically of zoned sodic bytownite and augite phenocrysts in a groundmass of andesine and augite microlites. Glass horizons are common within these lavas.

Utupua lies $65 \mathrm{~km}$ south-east of Nendö, and consists of a cone with a low-lying central crater of an extinct volcano. The rocks include inter-bedded ankaramitic porphyritic augite and olivine lavas with poorly porphyritic volcaniclastics, both of which have been intruded by dykes. The lava flows have red weathered upper surfaces which are indicative of subaerial deposition.

Vanikolo is a highly dissected volcanic complex formed of four coalesced volcanoes and includes porphyritic olivine augite basaltic lavas, volcaniclastics, sheet intrusions and dykes. Pillowed lavas are exposed on the coast, and probably represent the distal portions of subaerially erupted lava which flowed into the sea. The preservation of the Utupuan and Vanikolo volcanic forms suggest a possible Plio-Pleistocene age.

The Duff Islands are a chain of nine small islands situated about $145 \mathrm{~km}$ north-east of Nendö. The islands are formed of andesitic lavas, andesitic pyroclastic deposits and basaltic dykes. Agglomerates are common and grade into tuff beds, some of which are stratified. Most of the lava flows are massive but a few show pillowed structure.

Unlike Utupua and Vanikolo, no volcanic cone is preserved which suggests that the islands probably represent the uplifted remnants of an older, shallow submarine volcano of possible early Pliocene age.

Anuta is situated in the extreme eastern part of the Group. It is an eroded remnant of a once more extensive volcanic mass which remains as a shallow, submerged platform now around the island, and which resembles a flat-topped seamount in bathymetric pro- 
file. The volcanic rocks include olivine and labradorite-phyric basaltic andesite lavas and lamprobolite-oligoclase and augite oligoclase agglomerates.

Fatutaka is situated $35 \mathrm{~km}$ south-east of Anuta, and remains as an even smaller subaerial remnant of a once larger volcano. It is composed of labradoritic olivine basaltic andesite lavas with some agglomerates. Radiometric datings on two samples by JEZEK et al. (1977) give a reliable age of $2.2 \mathrm{my}$ and an uncertain age of $12.5 \mathrm{my}$.

Tikopia is a small island definite Pleistocene age dated as 80,000 years B.P. by FrYeR (1974). It is an extinct volcano, the central part of which has been enlarged by central collapse to form a pit crater whose south side has been breached. A slightly saline crater lake now occupies the centre of the island. The volcano is composite, with lava dominant over volcaniclastic material. The lavas are oligoclase augite andesites, but labradoritic olivine clasts dominate the agglomerates.

Tinakula is the only active volcano in the Group, and commenced eruption at least as early as 1595 (MARKham, 1904). The island has a subcircular outline, the slopes of which rise at an angle of $30^{\circ}$ to the summit at $851 \mathrm{~m}$. The composite cone consists of subaerial hypersthene andesitic lava and pyroclastic flows with olivine basalt clasts which have been intruded by labradoritic dolerite dykes. Fumerolic activity is continuous, but lava and pyroclastic flows are periodic.

Samples have only been collected from the Vitiaz Trench, in the east by FRYER (1974). These lava samples were dredged from the south-west wall, and all four samples show evidence of low grade metamorphism.

To summarise, five stages of volcanism can be recognized:

1) The earliest evidence of volcanism in the Group is that provided by the Oligocene lavas of Nendö.

2) A second stage is shown by Middle Miocene to early Pliocene lavas on Anuta and Fatutaka in the east of the Group.

3) Middle Pliocene volcanism represents the third stage, in which the AnutaFatutaka volcanism extended north-westerly to form the Duff Islands. Volcanism recommenced in the west by this time, as evidenced by the alkali basalt lavas on Nendö.

4) During the late Pliocene to Pleistocene, volcanism in the east ceased, with the late Fatutaka lavas dated at 2.2 my. Utupua and Vanikolo were produced in the west by a fourth stage of volcanism, which includes Tikopia at 80,000 years, in the central part of the area.

5) The final volcanic stage is that of the present day, in which Tinakula became, and still is, active.

The Eastern Outer Islands are situated upon a north-west extension of the submarine Fiji Plateau which lies beneath an average water depth of $3,600 \mathrm{~m}$ (MAMmERICKx et al., 1971) (Fig. 2). This is bounded on the west side by the New Hebrides or Torres Trench, situated $95 \mathrm{~km}$ off the west coasts of Nendö, Utupua and Vanikolo. The trench is a narrow, elongate oceanic depression with a maximum depth of $6,955 \mathrm{~m}$, and extends discontinuously southwards to the New Hebrides.

The north eastern limit of the area is marked by the south-east trending Vitiaz Trench, situated $270 \mathrm{~km}$ north east of Anuta, and with a maximum depth of $6,150 \mathrm{~m}$. To the north, the area is limited by a shallower westerly extension of the Vitiaz Trench known as the Cape Johnson Trough, while the southern limit to the area is the Hazel Holme Fracture Zone, which extends eastwards from Espiritu Santo in the northern New Hebrides.

Individual islands in the group rise steeply from the floor of the Plateau and, with the 


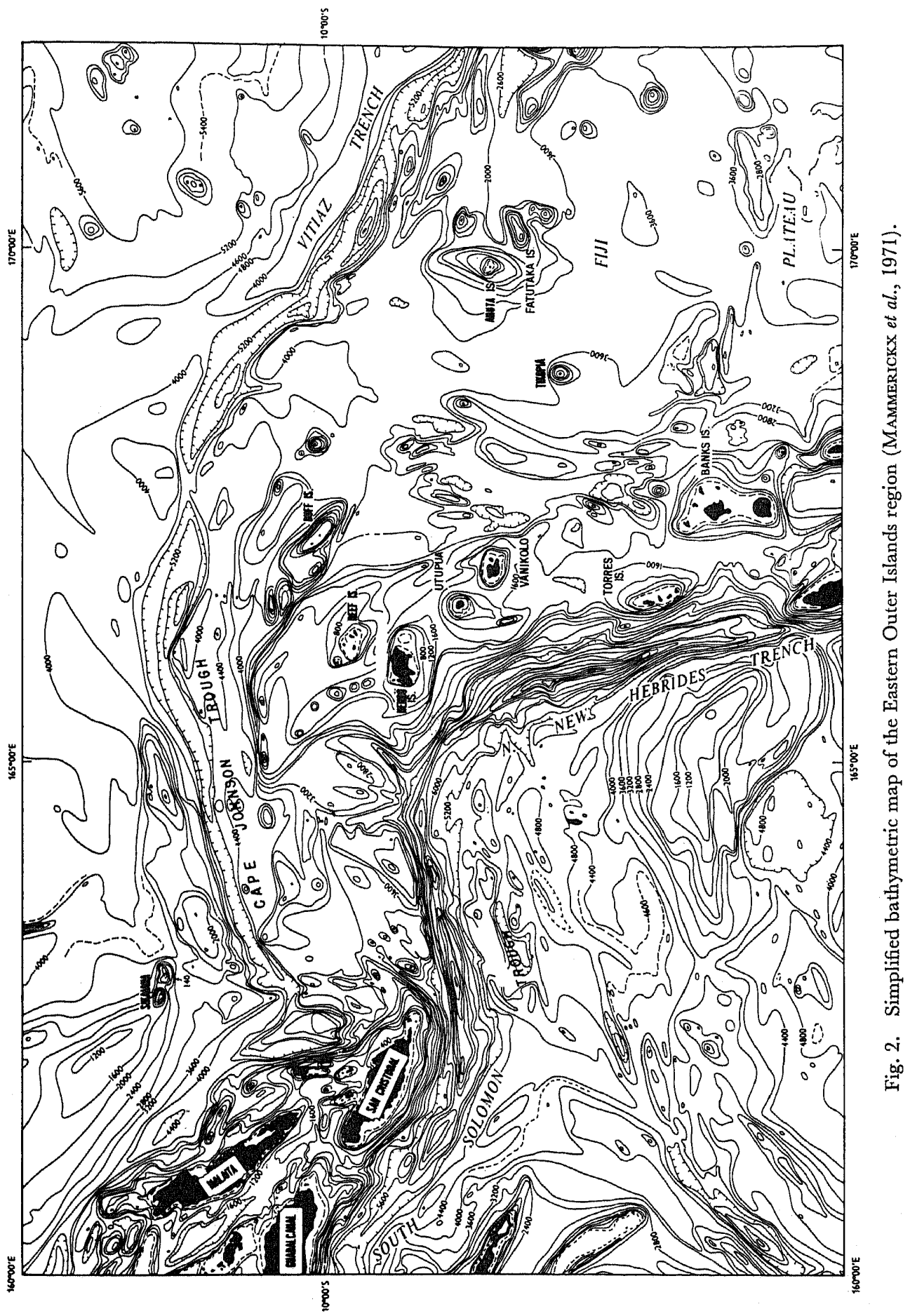




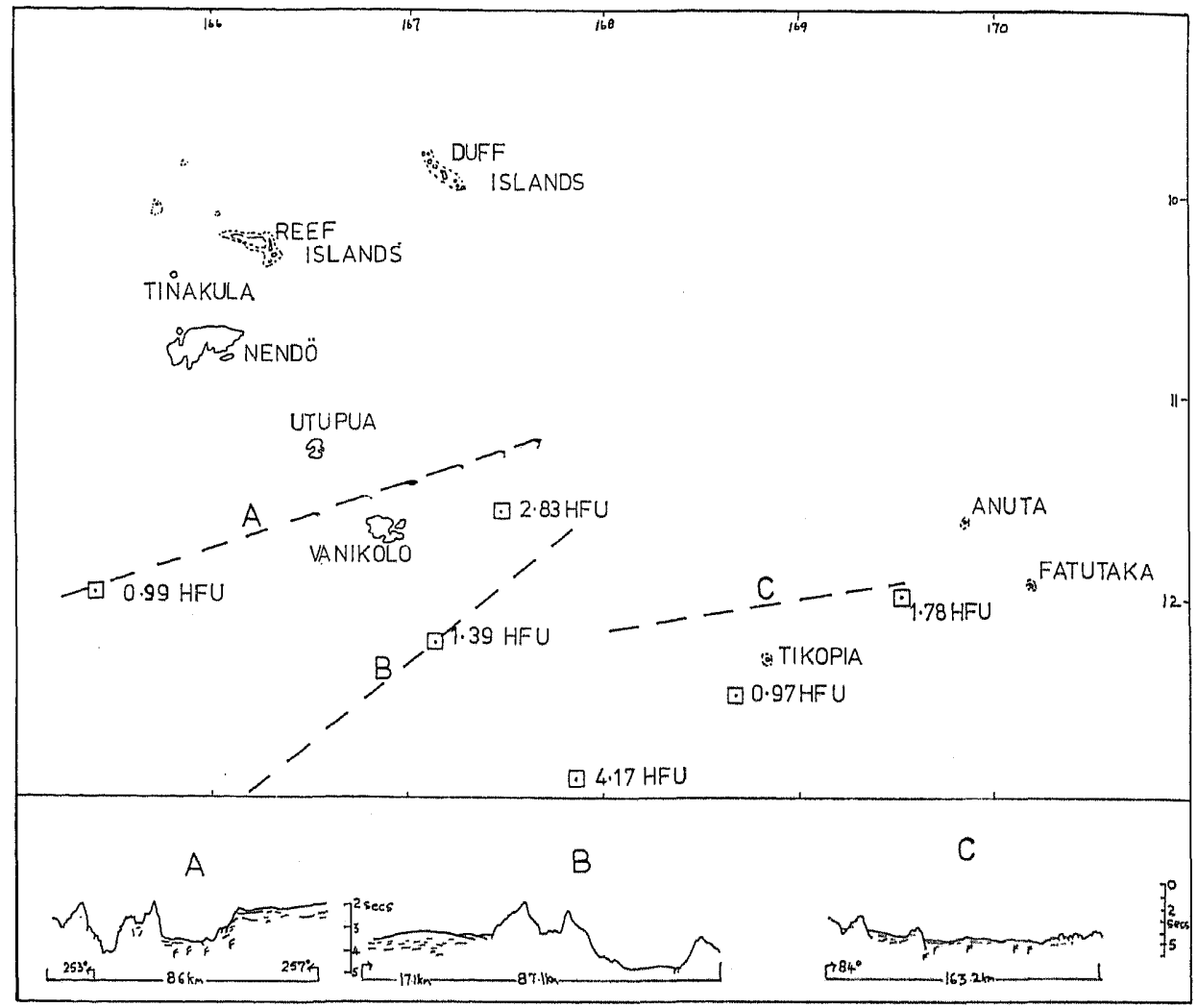

Fig. 3. Seismic reflection profiles and heat flow measurments (Luyendyk et al., 1974; MACDonald, 1973).

exception of Tinakula and Nendö, are not inter-connected by any well-defined submarine ridges. The Duff Islands are situated upon the crest of a single submarine ridge. Seismic reflection profiles carried out by LUYENDYk et al. (1974) (Fig. 3) reveal a rugged submarine relief along the western chain, especially in the vicinity of the Torres Trench.

The central part of the north Fiji Plateau (3rd profile) has a comparatively low relief, with sedimentary rocks disturbed only by minor faulting. The rather lobate features to the east possibly represent tightly folded sedimentary rocks resulting from compressional forces associated with the Vitiaz Trench.

This paper introduces the concept of two periodically active, converging subduction zones associated with the Torres and Vitiaz Trenches respectively, and combines previously unpublished geological data with geophysical data already published.

Rocks of basaltic composition have been analysed from all islands in the group, and include those rocks dredged from the Vitiaz Trench by FrYer (1974). Andesitic rocks display a more selective distribution, however, are found only on Tinakula, the Duffs, Tikopia and Anuta.

\subsection{The basalts}

Tholeiitic, high alumina and alkali basalts are recognized by their silica-alkali- 


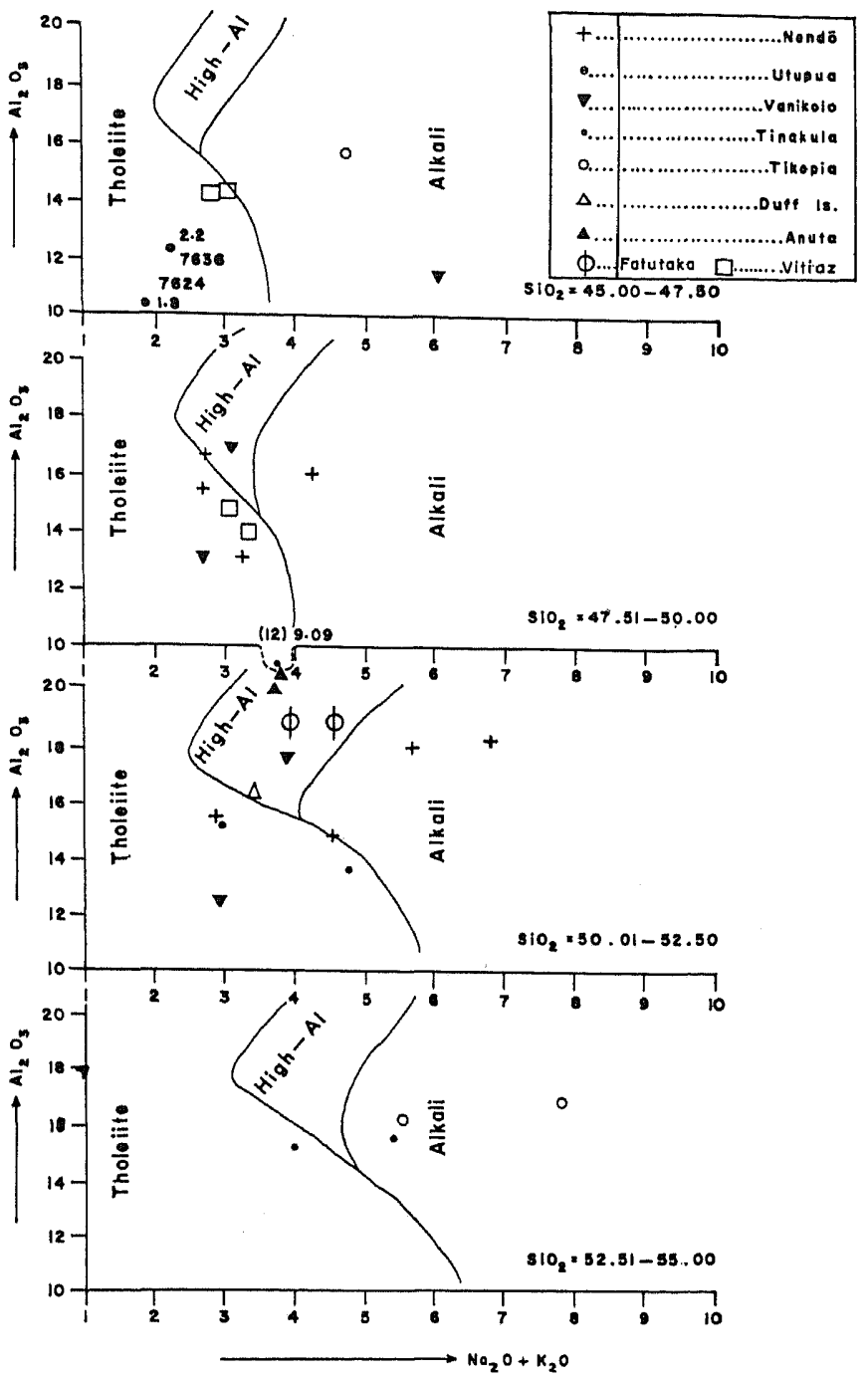

Fig. 4. Kuno's (1960) variation diagram for classification of the basaltic rocks from the Group.

alumina content on Kuno's (1960) variation diagram (Fig. 4). Two basaltic chemical compositions from the Duff Islands cannot be accommodated on Kuno's variation diagram however, and include a picrite basalt which is too low in silica, and a dyke rock which is too low in alumina.

Fourteen rocks fall into the field of tholeiitic basalt, ten of which come from the western island chain, the remaining four come from the Vitiaz Trench.

Nine rocks are here included within the alkali basalt type, and include six from the western chain and three from Tikopia. Whereas high alumina basalts are found exclusively in the Duffs, Anuta and Fatutaka samples, they are found with other basalt types on 


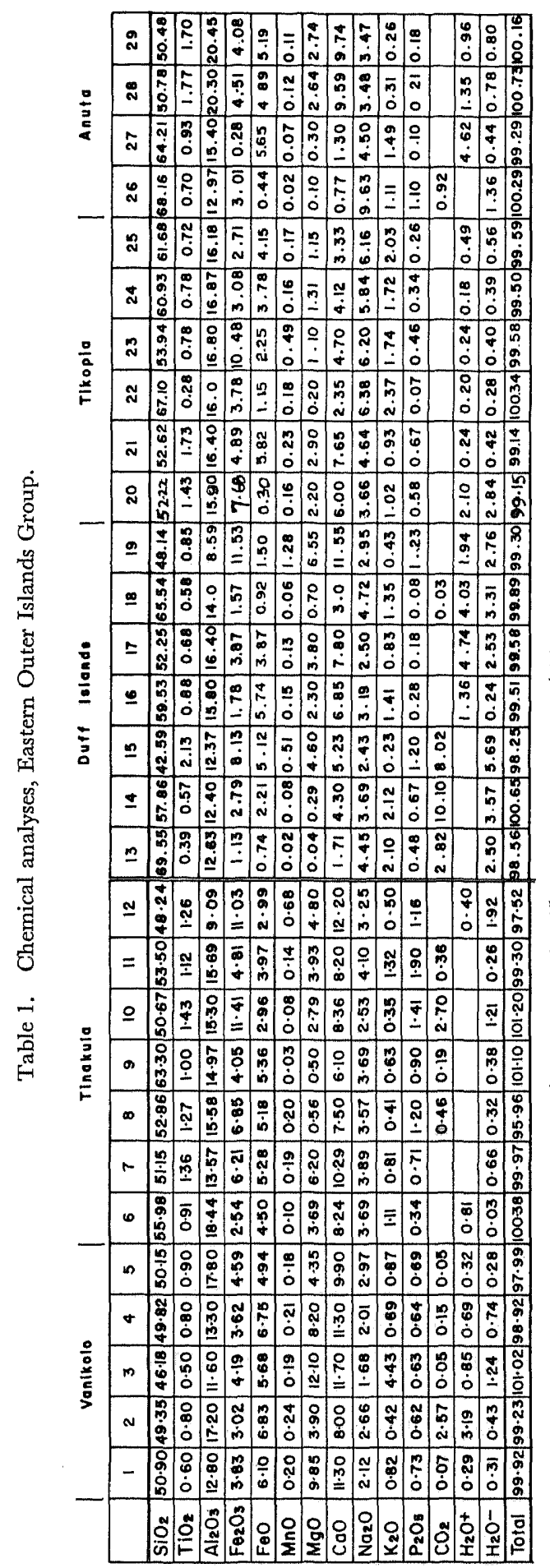

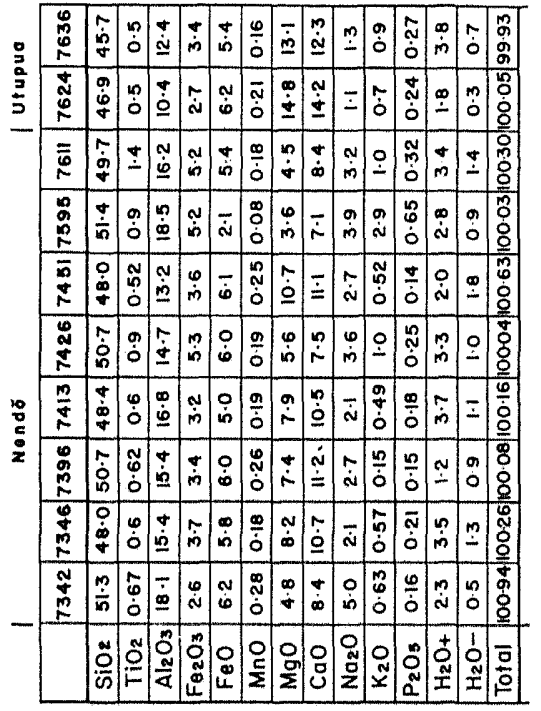


Nendö and Vanikolo. All four basalt samples from Anuta and Fatutaka are notably high in alumina and exceed $19.20 \% \mathrm{Al}_{2} \mathrm{O}_{3}$.

\subsection{The andesites}

Andesites have not been found on Nendö, Utupua, nor Vanikolo, but have been found among rocks from the other islands. They are grouped as low-silica and highsilica andesites and dacites, following Dickinson (1968)

Low-silica andesites contain between 55 and $60 \%$ silica, and include one from Tinakula and two from the Duff Islands.

High-silica andesites contain between 60 and $65 \%$ silica and include one from Tinakula, two from Tikopia and one from Anuta.

Dacitic rocks contain more than $65 \%$ silica, and include two from the Duff Islands, one from Tikopia and one from Anuta.

The distribution of analysed basaltic, andesitic and dacitic rock types in each island (Fig. 5) suggests a broad double trend in which predominantly tholeiitic basalts are found in the western chain of islands and also in the samples collected from the Vitiaz Trench. In the eastern chain and Tikopia, however, high alumina and alkali basalts are common, together with andesites and dacites. This pattern favours a situation in which both the Torres and Vitiaz subduction zones have contributed magmas at increasing stages of differentiation.

Figure 6 shows the relative variations in the range of weight per cent silica and average total iron in all analysed rocks, together with highest potash values in andesites. Islands of the western chain with the exception of Tinakula, together with Fatutaka and Vitiaz Trench samples show lowest silica range but highest total iron values. These proportions are reversed in the Duffs, Anuta, Tikopia and Tinakula, where highest silica range and lowest total iron values are found. Potash in the andesitic rocks displays higher values from the Duffs and Tikopia.

The overall pattern is one in which less mafic rocks are found in Tikopia in the central part of the region, and in the Duffs, both of which are situated almost mid-way between both trenches.

Three natural clusters are apparent on the AFM diagram (Fig. 7). One cluster indicates a trend towards magnesia enrichment, and includes samples from Nendö, Utupua and Vanikolo from the western chain with Anuta, Fatutaka and the Vitiaz Trench from the eastern chain.

The second cluster is a continuation of the first and shows a trend towards high alkali enrichment. Samples from Tikopia, the Duffs and Anuta are included within this suite.

Samples from Tinakula alone form the third cluster which shows a trend towards iron enrichment.

The most significant feature evident in the AFM diagram is that samples from the western chain, with the exception of Tinakula, plot within the same cluster as a number of samples from the eastern chain, and this coincidence is considered to suggest a similar petrogenesis. The trend towards alkali enrichment in some of the Duff Island, Anuta and Tikopia samples probably represents differentiation of the parent magma along the Vitiaz subduction zone.

The Tinakula samples exhibit a trend which originates in a parent magma which is common to most other islands in the Group, but which has become enriched in iron. 


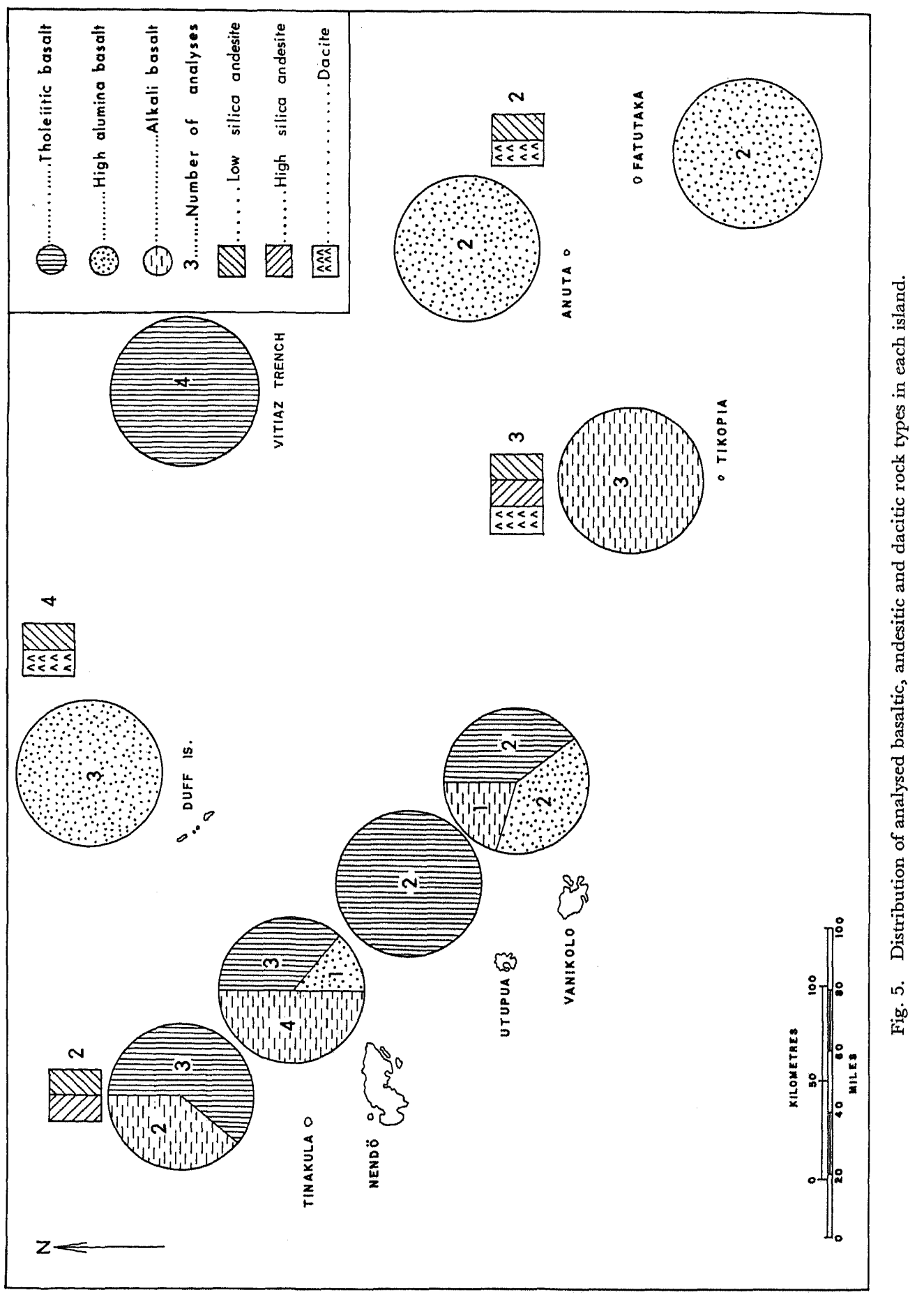


The Relationship between Volcanic Island Genesis and the Indo-Australian Pacific

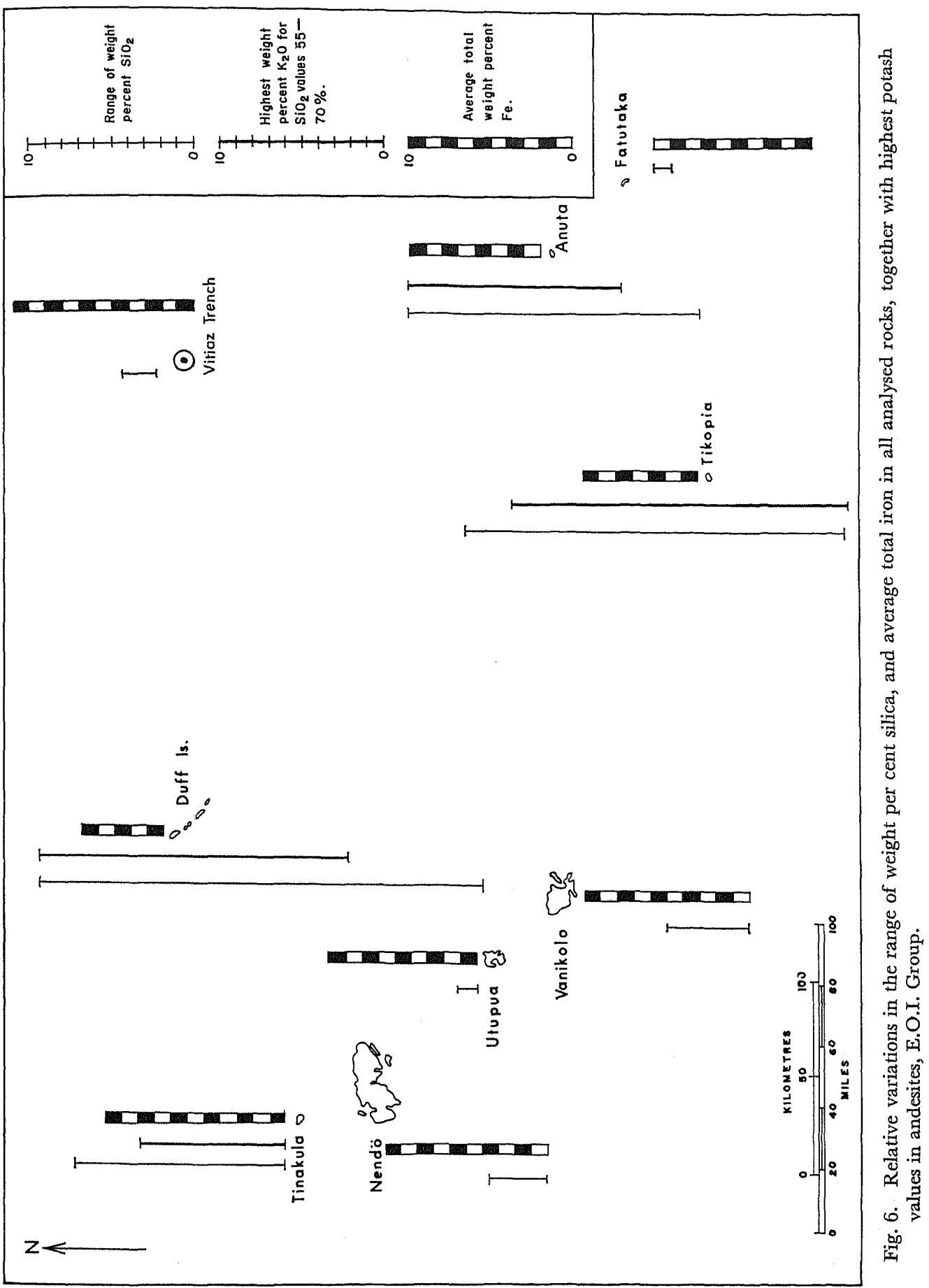




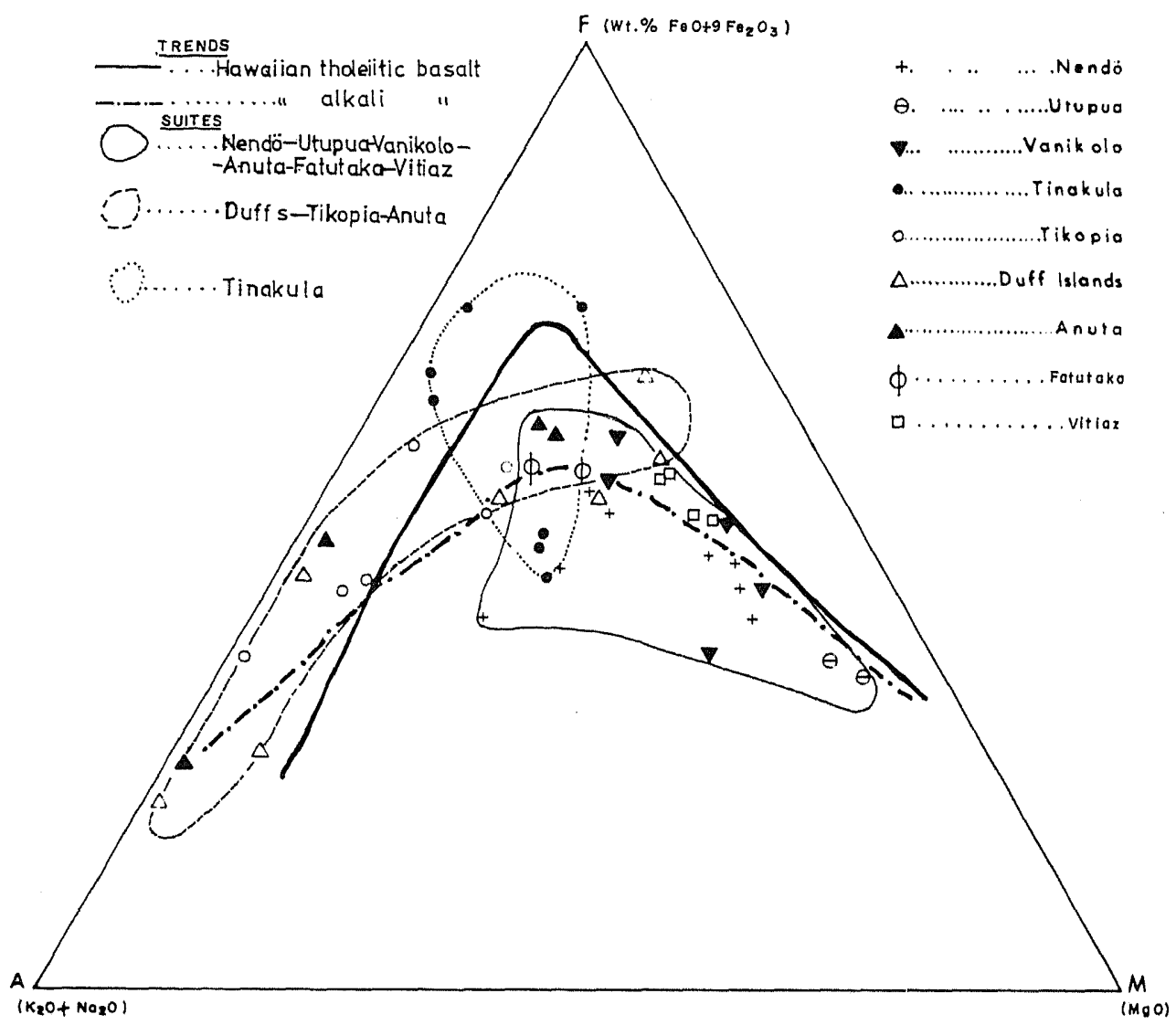

Fig. 7. AFM diagram illustrating calculated positions of all available analyses from islands in the E.O.I. Group.

Iron enrichment of rocks close to the Trench is attributed to early crystallization of olivine rather than magnetite (OsBorn, 1962).

Seismic data (Fig. 8) from the Eastern Outer Islands region clearly illustrate an increase in epicentre depth in relation to lateral distance north-eastwards away from the Torres Trench. This inclined plane of seismicity is considered to represent the inclined zone along which the oceanic floor lying south-west of Santa Cruz is being currently subducted in a north-easterly direction.

There are limited seismic data for the central part of the area except for a few deep epicentres situated south of Tikopia, and considered by Kroenke (personal communication) to represent a detached fragment of lithospheric material.

There is little seismic activity in the vicinity of the Vitiaz Trench, and available data indicate only one shallow epicentre in 1971 situated approximately $200 \mathrm{~km}$ north of Anuta. This evidence suggests that the Vitiaz Trench is a fossil trench associated with a subduction zone which recently became inactive.

Seismic velocities are high and LuYENDyx et al. (1974) suggest that the north Fiji Plateau consists of old oceanic lithosphere. 


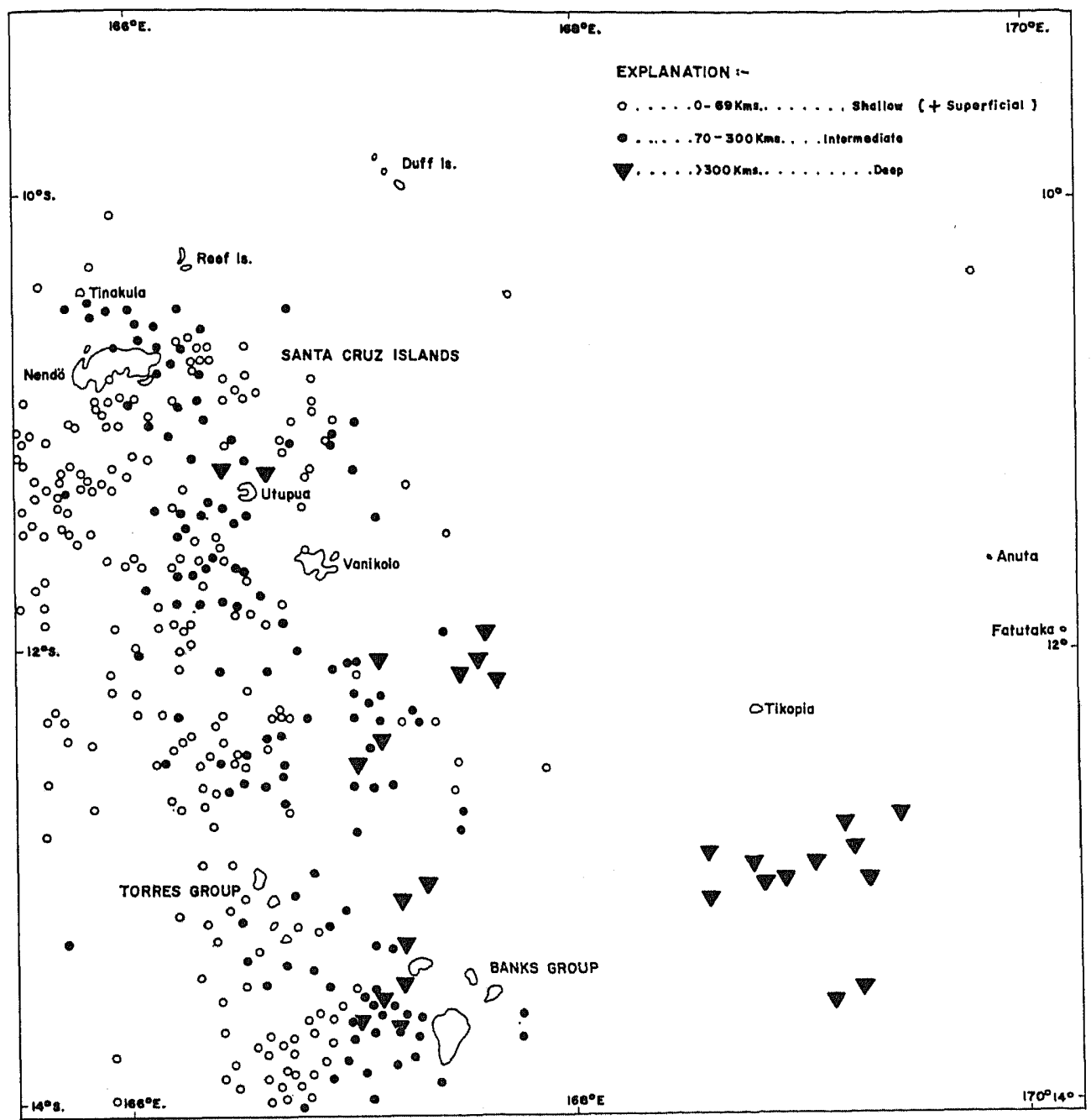

Fig. 8. Seismic data for the Eastern Outer Islands (D. Tuni, Seismological Division, Ministry of Natural Resources, Honiara, Solomon Islands).

Heat flow measurements north of the Hazel Holme Fracture Zone are generally lower than those to the south (MACDonald, 1973) (Fig. 3).

The low heat within the Torres Trench is probably the result of depression of the isotherms by the downgoing slab of lithosphere combined with rapid sedimentation. The higher measurements from stations between Vanikolo and Tikopia are attributed to subduction beneath and behind the island arc. The low heat flow near Anuta agrees with the trend of decreasing heat flow with further distance away from the active NendöVanikolo arc, but there is no evidence to suggest that subduction is currently taking place beneath and behind the Anuta-Fatutaka arc.

Magnetic trends are northerly, south of the fracture zone, but almost east-west in the north, as would be expected if the northern area was originally part of the Pacific Plate, and thus have an extrapolated late Cretaceous age. 


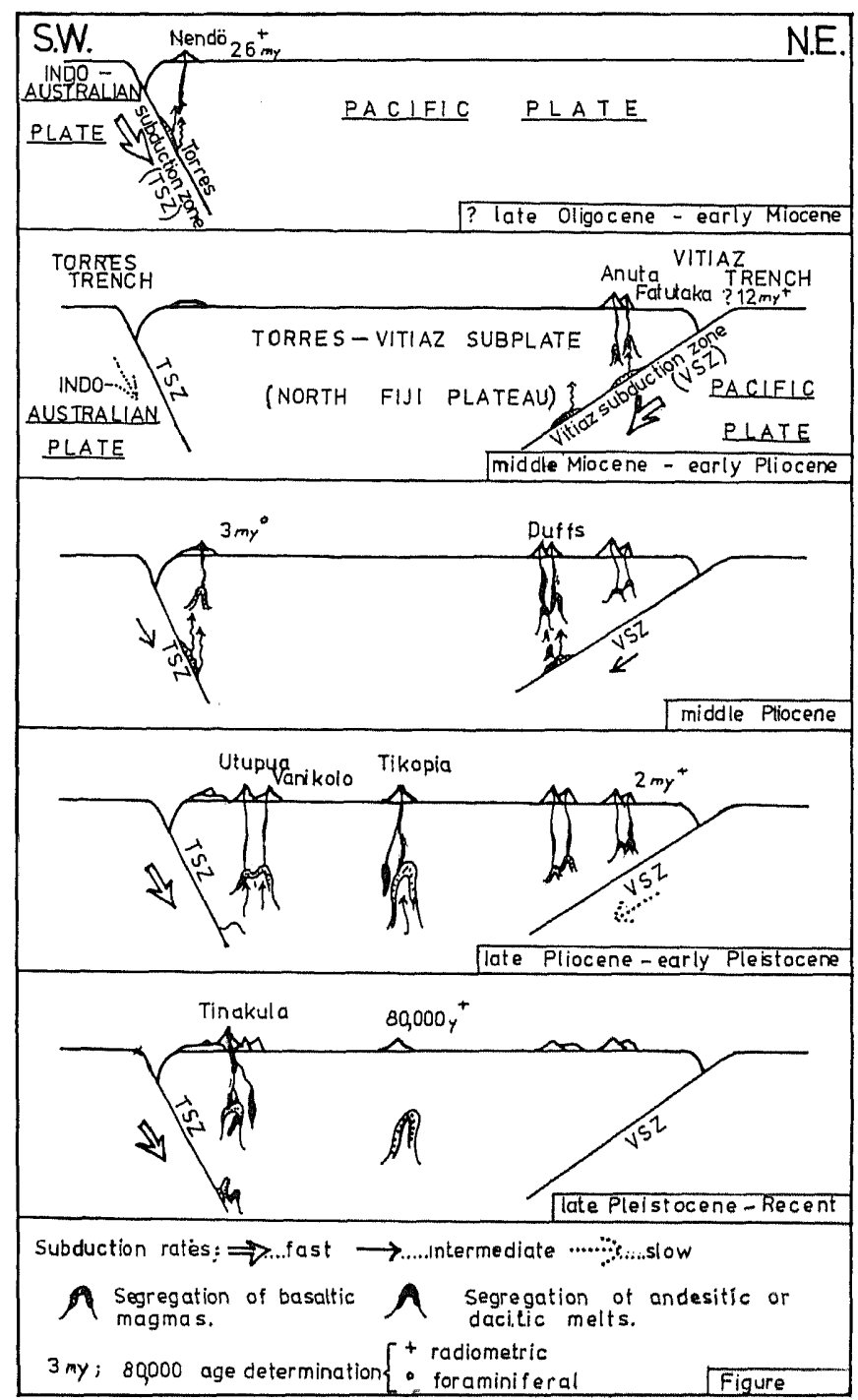

Fig. 9. Diagrams to illustrate a model depicting stages in the geological evolution of the E.O.I. Group.

\section{Summary of Volcanic Stages}

The five stages of volcanism described earlier can now be explained in terms of the petrochemical and geophysical evidence (Fig. 9).

Stage 1. The Oligocene to Lower Miocene tholeiitic basalts of Nendo provide the earliest evidence of volcanism within the group and have been radiometrically dated as $25 \mathrm{my}$ old. This volcanic episode is linked to subduction of the Indo-Australian Plate beneath the western Pacific Plate, associated with the Torres Trench. Grennbaum et al. (1975) have also described Oligocene to early Miocene volcanics from the Torres group 
and Carney and MacFarlane (in press) also suggest that easterly subduction at this time produced the western volcanic belt of the New Hebrides.

Stage 2. The Middle Miocene saw a new period of volcanism, which was situated in the eastern part, as evidenced by the 12.5 my old lavas on Fatutaka. This stage is attributed to the initiation of a new, westerly dipping subduction zone associated with the Vitiaz Trench, and which caused a simultaneous decline in Torres subductive activity. This caused part of the western Pacific Plate to be detached, and so form the north Fiji Plateau or Torres-Vitiaz subplate. Both Anuta and Fatutaka are considered to have been produced at this time, but unlike Nendö, tholeiitic lavas were not produced, and the presence of high alumina basalts and basaltic andesites is attributed to deeper melting (GREen and RINGWOOD, 1968) or possibly more prolonged fractionation down a shallower subduction zone than that associated with the Torres Trench.

Stage 3. In the Middle Pliocene, evidence that the Torres subduction zone became active again is provided by the alkali basalt flows on Nendö which lie within sedimentary rocks which contain planktonic foraminifera of Middle Pliocene age. The Vitiaz subduction zone was still active, and probably produced the Duff Island high alumina basalt, with high silica andesite and dacite volcanism at this time.

Stage 4. This stage ranges from the late Pliocene to Pleistocene, in which the final stage of volcanism in the east is dated at 2.2 my on Fatutaka lavas. The reduction in Vitiaz subduction was compensated by strong volcanism, and renewed subduction, associated with the Torres Trench in the west. The basaltic volcanoes of Utupua and Vanikolo were produced close to the Torres Trench. The alkali basalts, low- and high-silica andesites with dacites, on Tikopia, and dated at 80,000 years by FRYER (1974) are evidence for extreme differentiation of the parent magma beneath the central part of the area. Tikopia is situated midway between both trenches, but evidence for its association with Torres subduction is the coincidence of simultaneous volcanism with Utupua and Vanikolo, and suggests that the Torres subduction zone was probably involved in its genesis.

Stage 5. This stage includes the present day, when volcanic activity is restricted to the island of Tinakula. Low- and high-silica andesitic lavas with tholeiitic and alkali basalt clasts are produced. The active easterly dipping seismic zone associated with the Torres Trench provides little doubt that Tinakula magmas are derived from melting along the Torres subduction zone. The present attitude of the Torres seismic zone has been examined by WEST Wood (1970) whose results produce an angle of $60^{\circ}$ for the seismic plane, which dips towards the north-east at $\mathrm{N} 70^{\circ} \mathrm{E}$.

The active volcanoes of the southern Banks Islands, described by MALLICK and AsH (1975) are also considered to belong to this recent stage of volcanism.

\section{Conclusions}

1) Eastern Outer Islands are situated upon an interarc basin which is bordered by two recently active subduction zones.

2) Transfer of subduction from an original easterly direction to a later westerly direction and a final return to a presently active easterly direction was probably caused by differential rates of seafloor spreading in both the Indo-Australian and Pacific Plates. Another possible cause for cessation of westerly subduction may have been the approach of an unusually thickened portion of oceanic crust, similar to that of the Ontong Java Plateau; this mass may have effectively blocked, or choked, the Vitiaz subduction process. 
3) Petrologic and petrochemical variations can be explained in terms of two main trends, each of which is related to partial melting of a common parent magma associated with subduction beneath the western and eastern island arcs respectively. Both trends, of decreasing maficity of lavas converge towards the central part of the area. Differentiation of the magma within asthenospheric diapirs, rising from the subduction zone, is considered to be responsible for the variation of lava types within most islands. The petrochemical variations agree well with the model suggested by the bathymetric and geophysical data.

4) Compressional stresses were also relieved by anticlockwise rotation of the Vitiaz arc, resulting in oblique subduction. This was eventually replaced by strike-slip faulting which sheared off the subducted plate. The Cape Johnson Trough probably represents a westerly extension of this shear zone.

5) Geophysical evidence does not provide evidence for crustal spreading but rather that the Eastern Outer Islands are rooted in a detached segment of Pacific floor of possible late Cretaceous age, and which is considerably older than that to the south of the Hazel Holme Fracture Zone.

6) The Torres and Vitiaz trenches are so far apart in the study area that the stages involved in the development of the Eastern Outer Island Group, combined with the model of two converging subduction zones, may possibly be used to reconcile models envisaged for both the main Solomons chain and also for the New Hebrides Group. Theories regarding the evolution of the Torres and Vitiaz island arcs have now therefore been combined to form a unified history for this part of the northern Fiji Plateau.

\section{REFERENCES}

CARnex, J.N. and A. MACFARLane, Implications of a possible correlation between the late Tertiary geology of the New Hebrides and Fiji, (in press).

Dickinson, W.R., Circum-Pacific andesite types. J. Geophys. Res., 73, 2261-2269, 1968.

Fryer, P., Petrology of some volcanic rocks from the Northern Fiji Plateau, Geal. Soc. Am. Bull., 85, 1717-1720, 1974.

Green, D.H. and A.E. Ringwood, Genesis of the calc-alkaline igneous rock suite. Contr. Mineral. Petrol., 18, 105-162, 1968.

Greenbaum, D., D.I.J. Mallick, and N.W. Radford, The geology of the Torres Islands. Reg. Rep. New Hebrides Geol. Surv., 1-46, 1975.

Hughes, G.W. The geology and foraminiferal micropalaeontology of the Lungga and Itina basin areas, W. Guadalcanal, Solomon Islands, Ph. D. Thesis, Univ. of Wales, 1977.

Hughes, G.W., P.M. Craig, and R.A. Dennis, The geology of the Eastern Outer Islands, Bull. 4, Sol. Is. Geol. Dion., Min. Natl. Res. Honiara, (in press).

Jezek, P.A., W.B. Bryan, S.E. HAggerty, and H.P. Johnson, Petrography, petrology and tectonic implications of Mitre Island, northern Fiji Plateau, Marine Geol., 24, 123-148, 1977.

Kuno, H. High alumina basalt, J. Petrol., 1, 121-145, 1960.

Luyendyk, B.P., W.B. Bryan, and P.A. Jezek, Shallow structure of the New Hebrides Island Arc, Geol. Soc. Am. Bull., 85, 1287-1300, 1974.

MacDonald, K.C., Heat flow and plate boundaries in Melanesia, J. Geophys. Res., 78, 2537-2546, 1973.

Mallick, D.I.J. and R.P. Astr, Geology of the Southern Banks Islands, Reg. Rep. New Hebrides Geol. Surv, $1-33,1975$.

Mammerickx, J., T.E. Chiase, S.M. Smitri, and I.L. Taylor, Map, Bathymetry of the South Pacific, Calif. Scripps Inst. of Oceanography, 1971.

MarkhaM, C.R. The voyages of Pedro Fernandez de Quiros, 1595-1606, Hakluyt Soc. (London), 11, 14-15, 1904.

OsBorn, E.F., Reaction series for subalkaline igneous rocks based on different oxygen pressure conditions, Am. Mineral., 47, 211-226, 1962.

Westwoon, J.V.B., Seismicity of the Solomon and Santa Cruz Islands, southwest Pacific, J. Geol. Soc. Aust, 17, 87-92, 1970. 